\title{
PERILAKU PETANI DALAM USAHATANI MANGGA DI KABUPATEN CIREBON
}

\section{BEHAVIOR OF FARMERS IN MANGO FARMING IN CIREBON REGENCY}

\author{
Rani Andriani Budi Kusumo*, Elly Rasmikayati, Gema Wibawa Mukti \\ Program Studi Agribisnis Fakultas Pertanian Universitas Padjadjaran \\ Jl. Raya Jatinangor Sumedang Km. 21 \\ *Email: raniandriani081@gmail.com
}

(Diterima 29-06-2018; Disetujui 13-07-2018)

\begin{abstract}
ABSTRAK
Sebagai salah satu produsen mangga terbesar di dunia, masih terdapat permasalahan dalam hal kualitas produk serta produktivitas hasil yang masih rendah. Kuantitas dan kualitas mangga yang dihasilkan petani sangat dipengaruhi oleh perilaku petani mangga dalam aktivitas usahataninya. Tujuan dari penelitian ini adalah untuk menganalisis: 1) persepsi petani terhadap usahatani mangga di Kabupaten Cirebon; 2) perilaku petani dalam usahatani mangga di Kabupaten Cirebon; 3) Faktor-faktor yang berhubungan dengan perilaku petani dalam usahatani mangga di Kabupaten Cirebon. Penelitian dilakukan dengan metode survey-eksplanatory. Responden dalam penelitian ini adalah 130 orang petani mangga yang diambil secara acak dengan teknik multi-stage random sampling. Analisis statistika deskriptif dan analisis korelasi rank Spearman digunakan untuk menjawab tujuan penelitian. Hasil analisis menunjukkan sebagian besar petani belum menerapkan teknis pemupukan, penggunaan zat pengatur tumbuh dan penanganan hama penyakit sesuai anjuran. Stabilitas harga merupakan faktor yang berhubungan dengan perilaku petani dalam berbagai aktivitas usahataninya. Diperlukan upaya untuk menjamin stabilitas harga yang diterima oleh petani agar petani lebih termotivasi untuk meningkatkan produktivitas dan kualitas hasil.
\end{abstract}

Kata kunci: mangga, perilaku, petani, usahatani

\begin{abstract}
As one of the largest mango producers in the world, there are still problems faced by farmers in terms of product quality and productivity. The quantity and quality of mango produced by farmers is influenced by the behavior of mango farmers in their farming activities. This research were aimed to analyze: 1) farmers perception of mango farming in Cirebon Regency; 2) behavior of farmers in mango farming in Cirebon Regency; 3) Factors related to farmer behavior in mango farming in Cirebon Regency. The research was conducted by survey-explanatory method. Respondents in this study were 130 mango farmers who were taken at random by multi-stage random sampling technique. Descriptive statistical analysis and Spearman rank correlation analysis were used to answer the research objectives. The result of analysis showed that most farmers have not applied fertilization technique, the use of growth regulators and pest management as recommended. Price stability was a factor associated with farmer behavior in various activities of his farming. Efforts were needed to ensure price stability received by farmers so that farmers are more motivated to improve productivity and yield quality.
\end{abstract}

Keywords: mango, behavior, farmers, farming 


\section{PENDAHULUAN}

Indonesia merupakan salah satu produsen mangga terbesar di dunia. Direktorat Jenderal Hortikultura menyebutkan selama kurun waktu Tahun 2010-2014, produksi mangga Indonesia terus mengalami peningkatan. Pada Tahun 2014, produksi mangga nasional sebesar 2,464 juta ton ${ }^{1}$. Jawa Barat merupakan daerah penghasil mangga ketiga terbesar di Indonesia, setelah Provinsi Jawa Timur dan Jawa Tengah, dilihat dari luas panen dan volume produksi (Pusat Data dan Informasi Kementerian Pertanian, 2014). Sentra produksi mangga di Provinsi Jawa Barat diantaranya adalah Kabupaten Cirebon, Indramayu, Kuningan, Majalengka dan Sumedang.

Sejalan dengan produksi mangga nasional, produksi mangga di sentra produksi di Jawa Barat dalam kurun waktu tahun 2010-2014 menunjukkan peningkatan. Namun pada tahun 2015, produksi mangga di beberapa daerah penghasil mangga mengalami penurunan. Salah satu daerah yang mengalami penurunan produksi mangga adalah Kabupaten Cirebon (Tabel 1).

\footnotetext{
${ }^{1}$ Diakses melalui situs https://aplikasi.pertanian.go.id/bdsp/hasil_kom.as p, tanggal 5Mei 2018
}

Penurunan tingkat produksi mangga di Kabupaten Cirebon selain disebabkan oleh serangan hama, juga disebabkan oleh permasalahan lain dalam agribisnis mangga. Petani mangga di Kabupaten Cirebon saat ini menghadapi permasalahan kualitas produk yang belum seragam serta produktifitas hasil yang masih rendah. Salah satu akar penyebab dari persoalan ini adalah masih lemahnya kapasitas dan kapabilitas dari petani itu sendiri dalam mengelola usahatani mangga, sehingga berimbas pada hasil yang diperoleh (Deliana, 2012). Direktorat Jenderal Hortikultura (2011) juga menyampaikan hal yang serupa, bahwa permasalahan dalam pengembangan tanaman hortikultura, termasuk dalam hal ini mangga, antara lain budidaya yang masih konvensional, produktivitas dan mutu buah yang rendah, penanganan pasca panen yang kurang baik, skala usaha yang kecil dan berpencar, kelembagaan yang belum mapan, aksesibilitas yang kurang baik, kurangnya dukungan infrastruktur, serta keterbatasan modal petani. Di sisi lain, persaingan di era pasar bebas menuntut petani untuk menghasilkan produk yang berkualitas, tidak hanya untuk memenuhi permintaan pasar ekspor tetapi juga untuk memenuhi permintaan pasar dalam negeri 
agar buah mangga produksi petani lokal mampu bersaing dengan buah mangga dari negara lain.

Tabel 1. Produksi Mangga di Daerah Sentra Mangga Jawa Barat

\begin{tabular}{lcccccc}
\hline \multirow{2}{*}{ Kabupaten } & \multicolumn{7}{c}{ Produksi Mangga (Ton) } \\
\cline { 2 - 8 } & $\mathbf{2 0 1 0}$ & $\mathbf{2 0 1 1}$ & $\mathbf{2 0 1 2}$ & $\mathbf{2 0 1 3}$ & $\mathbf{2 0 1 4}$ & $\mathbf{2 0 1 5}$ \\
\hline Kuningan & 5.528 & 44.868 & 39.377 & 32.406 & 23.329 & 32.108 \\
\hline Cirebon & 13.077 & 55.981 & 62.053 & 30.945 & 51.661 & 37.443 \\
\hline Majalengka & 16.431 & 43.280 & 48.521 & 10.243 & 57.172 & 64.394 \\
\hline Sumedang & 17.534 & 21.169 & 29.008 & 23.607 & 20.633 & 23.491 \\
\hline Indramayu & 35.826 & 63.057 & 68.506 & 84.788 & 72.436 & 69.737 \\
\hline
\end{tabular}

Sumber: BPS, 2015

Kuantitas dan kualitas mangga yang dihasilkan petani sangat dipengaruhi oleh perilaku petani mangga dalam aktivitas usahataninya. Pemahaman mengenai perilaku petani diperlukan untuk memberikan gambaran mengenai kapasitas petani mangga sebagai upaya memperbaiki dan meningkatkan perilaku agribisnis petani secara menyeluruh dari mulai proses produksi hingga pemasaran.

Perilaku petani dipengaruhi oleh faktor eksternal dan internal. Faktor internal dalam diri petani dapat digambarkan melalui karakteristik petani dan persepsi petani terhadap usahatani yang dijalankannya. Persepsi merupakan salah satu faktor internal yang mendorong timbulnya perilaku. Rakhmat (2004) menyebutkan persepsi merupakan pengalaman belajar tentang objek peristiwa atau hubungan-hubungan yang diperoleh dengan menyimpulkan informasi atau menafsirkan pesan. Penelitian Ameriana (2008) dan Amin (2014) menunjukkan terdapat hubungan yang signifikan antara persepsi petani terhadap usahatani dengan perilaku petani dalam menjalankan usahataninya.

Berdasarkan pemaparan di atas, tujuan dari penelitian ini adalah untuk menganalisis: 1) persepsi petani terhadap usahatani mangga di Kabupaten Cirebon; 2) perilaku petani dalam usahatani mangga di Kabupaten Cirebon; 3)Faktorfaktor yang berhubungan denganperilaku petani dalam usahatani mangga di Kabupaten Cirebon.

\section{METODE PENELITIAN}

Penelitian ini merupakan bagian dari penelitian payung yang berjudul "Era Globalisasi: Upaya Peningkatan Kapasaitas Petani Mangga di Pasar 
Modern Ditinjau dari Dinamika Agribisnis dan Penguasaan Lahannya”.

Penelitian dilakukan dengan metode survey-eksplanatory, dengan pengambilan sampel multi-stage random sampling. Tahapannya adalah memilih satu kecamatan yang merupakan sentra mangga di Kabupaten Cirebon (yaitu Kecamatan Greged), selanjutnya menentukan dua desa sentra mangga. Masing-masing desa diambil responden petani secara random 65 responden, sehingga jumlah total responden petani mangga adalah sebanyak 130 orang. BPS mendefinisikan petani mangga adalah keluarga petani yang memiliki 4 pohon mangga atau lebih.

Variabel yang diteliti dalam penelitian ini adalah:

1. Karakteristik petani yang meliputi: umur, tingkat pendidikan, jumlah pohon yang diusahakan, pengalaman usahatani mangga, frekuensi mengikuti kegiatan penyuluhan, keanggotaan dalam kelompok tani, kemitraan dalam pemasaran, akses terhadap informasi mengenai budidaya mangga, dan pemasaran mangga.

2. Persepsi petani terhadap kelayakan usahatani mangga adalah pernyataan responden tentang permintaan mangga, dan harga jual mangga, yang diukur melalui item pertanyaan dengan 5 poin Skala Likert.

3. Perilaku petani dalam agribisnis mangga adalah tindakan atau aktivitas yang dilakukan petani dalam menjalankan agribisnis mangga, diukur melalui melalui item pertanyaan dengan 5 poin Skala Likert.

Data yang digunakan dalam penelitian ini adalah data primer dan data sekunder. Data primer merupakan data yang diperoleh langsung dari hasil wawancara dengan petani mangga di Kabupaten.Cirebon. Sedangkan data sekunder diperoleh dari Badan Pusat Statistik, Data Dinas Pertanian Kabupaten Cirebon dan berbagai sumber lainnya. Teknik pengumpulan data dilakukan melalui: 1) wawancara dengan panduan kuesioner, dan 2) pengamatan langsung (observasi) di lokasi penelitian.

Analisis statistika deskriptif digunakan untuk menjawab pertanyaan penelitian mengenai karakteristik sosial ekonomi petani mangga di Kabupaten Cirebon. Untuk mengetahui hubungan antara persepsi petani mangga dengan perilaku petani dalam usahatani mangga di Kabupaten Cirebon digunakan analisis korelasi Rank Spearman. 
HASIL DAN PEMBAHASAN

\section{Karakteristik Sosial Ekonomi Responden}

Karakteristik sosial ekonomi responden digambarkan berdasarkan umur, tingkat pendidikan, jumlah pohon yang dimiliki, pengalaman usahatani, frekuensi mengikuti kegiatan penyuluhan, keikutsertaan dalam kelompok tani dan kemitraan dalam pemasaran mangga. Badan Pusat Statistik (BPS) mendefinisikan penduduk usia produktif adalah penduduk yang berusia antara 15-64 tahun. Berdasarkan hal tersebut, dapat dijelaskan bahwa sebagian besar petani mangga di Kabupaten Cirebon $(93,85 \%)$ berada pada usia produktif, dengan rata-rata umur responden adalah 52,44 tahun (Tabel 2). Usia petani berpengaruh terhadap kemampuan fisik dalam menjalankan aktivitas usahatani.

Tingkat pendidikan diukur dari pendidikan formal yang ditempuh oleh responden. Tingkat pendidikan berhubungan dengan pengetahuan dan keterampilan petani dalam mengelola usahataninya (Burton, 2014). Tingkat pendidikan responden tergolong rendah, sebagian besar responden $(71,54 \%)$ hanya menempuh pendidikan hingga tingkat sekolah dasar, bahkan ada beberapa responden yang tidak menempuh pendidikan formal.

Jumlah pohon mangga yang diusahakan oleh responden baik milik sendiri, sakap ataupun sewa dapat menggambarkan kapasitas produksi. BPS mengelompokkan petani dengan kepemilikan pohon mangga 4-10 pohon dikategorikan sebagai petani halaman (backyard farmer). Sedangkan petani yang memiliki 11 pohon ke atas dikategorikan sebagai petani kebun (commercial farmer). Berdasarkan kategori tersebut, seluruh petani responden tergolong pada petani kebun, dan sebagian besar responden $(63,08 \%)$ mengusahakan pohon mangga kurang dari 100 pohon. Dilihat dari pengalaman usahatani, separuh jumlah responden $(49,23 \%)$ memiliki pengalaman usahatani kurang dari 10 tahun.

Setiana (2005) mengemukakan bahwa penyuluhan merupakan sumber informasi yang berperan dalam menjembatani antara pengetahuan dan teknologi yang selalu berkembang dengan kegiatan usahatani yang dijalankan oleh petani. Pada awal kegiatan pengembangan mangga gedong gincu sebagai komoditas unggulan daerah dilaksanakan, penyuluhan rutin dilakukan secara berkala setiap tahunnya, kegiatan 
penyuluhan meliputi pelatihan teknik budidaya, penanganan hama dan penyakit, serta pelatihan pembuatan obat dan pestisida nabati. Namun saat ini kegiatan penyuluhan jaarang dilakukan.
Sebagian besar petani $(52,31 \%)$ hanya mengikuti kegiatan penyuluhan 1-2 kali per tahun, bahkan ada petani yang tidak pernah mengikuti kegiatan penyuluhan (Tabel 2).

\section{Tabel 2. Karakteristik Sosial Ekonomi Responden}

\begin{tabular}{|c|c|c|}
\hline Karakteristik & n (orang) & $\%$ \\
\hline \multicolumn{3}{|l|}{ Umur } \\
\hline Produktif (15-64 tahun) & 122 & 93,85 \\
\hline Non Produktif (>64 tahun) & 8 & 6,15 \\
\hline Rata-rata umur: 52,44 tahun & & \\
\hline \multicolumn{3}{|l|}{ Tingkat pendidikan } \\
\hline Tidak Sekolah & 5 & 3,85 \\
\hline $\mathrm{SD}$ & 93 & 71,54 \\
\hline SMP & 24 & 18,46 \\
\hline SMA & 6 & 4,62 \\
\hline Diploma & 1 & 0,77 \\
\hline Sarjana & 1 & 0,77 \\
\hline \multicolumn{3}{|l|}{ Jumlah pohon yang dimiliki } \\
\hline$\leq 10$ & 0 & 0 \\
\hline $11-100$ & 82 & 63,08 \\
\hline $101-200$ & 25 & 19,23 \\
\hline 201-300 & 9 & 6,92 \\
\hline $301-400$ & 1 & 0,77 \\
\hline$\geq 401$ & 13 & 10,00 \\
\hline \multicolumn{3}{|l|}{ Pengalaman usahatani (tahun) } \\
\hline $0-10$ & 64 & 49,23 \\
\hline $11-20$ & 40 & 30,77 \\
\hline $21-30$ & 22 & 16,92 \\
\hline $31-40$ & 2 & 1,54 \\
\hline $41-50$ & 1 & 0,7 \\
\hline$>50$ & 1 & 0,77 \\
\hline \multicolumn{3}{|c|}{ Frekuensi mengikuti kegiatan penyuluhan (per tahun) } \\
\hline Tidak pernah & 10 & 7,69 \\
\hline $1-2 x$ & 68 & 52,31 \\
\hline $3-6 \mathrm{x}$ & 49 & 37,69 \\
\hline $7-10 x$ & 3 & 2,31 \\
\hline \multicolumn{3}{|l|}{ Keanggotaan dalam kelompok tani } \\
\hline Ya & 111 & 85,38 \\
\hline Tidak & 19 & 14,62 \\
\hline \multicolumn{3}{|l|}{ Bermitra dalam pemasaran mangga } \\
\hline Ya & 37 & 28,46 \\
\hline Tidak & 93 & 71,54 \\
\hline
\end{tabular}


Kelompok tani merupakan wadah bagi para petani untuk saling berbagi informasi dan berdiskusi mengenai kegiatan pengadaan input produksi, budidaya, dan pemasaran. Sebagian besar responden $(85,38 \%)$ tergabung dalam kelompok tani (Tabel 1). Bagi anggota kelompok tani biasanya terdapat kegiatan penyuluhan rutin yang diselenggarakan minimal satu tahun sekali.

Keputusan Menteri Pertanian Nomor 940 Tahun 1997 menyebutkan bahwa kemitraan adalah kerjasama usaha antara perusahaan mitra dengan kelompok mitra di bidang usaha pertanian. Kemitraan merupakan upaya untuk memberdayakan kelompok mitra dalam pembangunan pertanian yang berorientasi agribisnis. Di Kabupaten Cirebon hanya sebagian kecil petani $(28,46 \%)$ yang menjalin kemitraan (Tabel 1). Pada umumnya kemitraan yang terjalin antara petani mangga dan mitra di Kabupaten Cirebon adalah kemitraan pada pemasaran buah. Biasanya kelompok tani bermitra dengan perusahaan pemasok buah segar seperti PT. Asri Duta Pertiwi, PT. Alamanda, PT. Alindo, dan CV. Sumber Buah SAE. Namun kemitraan tidak dilakukan dengan kontrak, sehingga pemasaran mangga produksi petani hanya melalui sistem pre- order. Peran ketua kelompok dalam mencari mitra kerja sangat mempengaruhi perkembangan keberhasilan usaha tani kelompok dan anggotanya.

\section{Persepsi Petani terhadap Usahatani Mangga}

Persepsi petani terhadap usahatani mangga diukur melalui pernyataan petani mengenai permintaan buah mangga dan harga jual mangga. Pada Tabel 3 dapat dilihat bahwa separuh responden $(51,54 \%)$ menyatakan permintaan konsumen terhadap buah mangga cukup tinggi. Selama ini petani merasa tidak pernah merasa kesulitan dalam memasarkan mangga. Sebagian besar petani menjual semua hasil panennya melalui kelompok petani dan pedagang pengumpul yang datang ke kebun milik petani, bahkan sebagian petani menjual mangganya dengan sistem tebasan. Mangga grade $\mathrm{A} / \mathrm{B}$ sebagian besar disalurkan ke pasar-pasar induk di berbagai daerah, pasar modern dan sebagian kecil dijual ke pasar ekspor. Sedangkan mangga grade $\mathrm{C}$ biasanya disalurkan ke pasar-pasar tradisional di Kabupaten Cirebon dan daerah sekitarnya (Data primer, 2017). 
Tabel 3. Persepsi Petani terhadap Kelayakan Usahatani Mangga

\begin{tabular}{lrr}
\hline \multicolumn{1}{c}{ Persepsi Petani } & n (orang) & \multicolumn{1}{c}{$\%$} \\
\hline Permintaan buah mangga & & \\
\hline Sangat tinggi & 8 & 6,15 \\
Tinggi & 53 & 40,77 \\
Cukup tinggi & 67 & 51,54 \\
Rendah & 2 & 1,54 \\
Sangat rendah & - & 0,00 \\
\hline Harga jual mangga & & \\
\hline Sangat tinggi & 11 & 8,46 \\
Tinggi & 57 & 43,85 \\
Cukup tinggi & 53 & 40,77 \\
Rendah & 9 & 6,92 \\
Sangat rendah & 0 & 0,00 \\
\hline
\end{tabular}

Dalam penentuan harga jual mangga, sebagian besar petani berada pada posisi penerima harga. Harga jual mangga lebih kuat ditentukan oleh pedagang pengumpul. Sebagian besar petani menilai harga jual mangga saat ini cukup baik karena petani merasakan keuntungan dari usahatani mangga yang mereka jalankan. Yang menjadi permasalahan bagi petani adalah fluktuasi harga dimana ketidakpastian harga yang diterima oleh petani menjadi kendala bagi petani untuk melakukan intensifikasi usaha.

\section{Perilaku Petani dalam Usahatani Mangga}

Perilaku petani dalam usahatani mangga dianalisis melalui aktivitas petani dalam merawat tanaman mangga. Pada Tabel 4 dapat dilihat bahwa sebagian besar petani tidak terlalu intensif dalam merawat pohon mangga. Banyak petani yang belum mengikuti anjuran teknis budidaya mangga sesuai dengan anjuran dari Dinas Pertanian.

Dalam menerapkan sistem pemupukan, sebagian besar petani melakukannya berdasarkan pengalaman sebelumnya atau berdasarkan informasi petani lain, hanya sebagian kecil petani $(4,62 \%)$ yang selalu mengikuti rekomendasi pemupukan dari pemerintah (Tabel 4). Dirjen Bina Produksi Hortikultura (2004) merekomendasikan pemberian pupuk per hektar untuk tanaman mangga yaitu $75 \mathrm{Kg}$ NPK dan $860 \mathrm{Kg}$ pupuk kandang. Sebagian besar petani hanya memberikan satu jenis pupuk untuk tanaman mangga. Hal tersebut dikarenakan keterbatasan modal yang dimiliki petani serta harga jual mangga yang tidak menentu. Hasil penelitian Supriatna dan Sudana (2008) menyebutkan bahwa kebanyakan petani menggunakan zat pengatur tumbuh untuk 'memaksa' tanaman mangga untuk berproduksi tinggi tanpa diikuti oleh pemupukan yang memadai.

Penggunaan zat pengatur tumbuh selain bertujuan untuk meningkatkan hasil produksi juga sebagai upaya untuk memacu produksi mangga di luar musim. Yuniastuti et al (2012) menjelaskan keberhasilan pemacuan pembungaan 
memerlukan teknologi pengelolaan tanaman secara spesifik agar bunga yang terbentuk tidak mudah rontok akibat hujan serta produktivitas dan mutu buah mangga yang dihasilkan dapat meningkat. Pemberian unsur hara makro dan mikro sesuai kebutuhan tanaman serta pengendalian hama penyakit secara intensif merupakan salah satu cara untuk meningkatkan produktivitas dan mutu buah mangga. Sebagian besar petani belum menerapkan penggunaan zat pengatur tumbuh sesuai aturan (Tabel 4). Dinas Pertanian Kabupaten Cirebon (2004) menjelaskan bahwa jika hal tersebut terus dilakukan, pada akhirnya kuantitas dan kualitas mangga yang dihasilkan akan terus menurun.

Tabel 4. Perilaku Petani dalam Usahatani Mangga

\begin{tabular}{lrr}
\hline \multicolumn{1}{c}{ Perilaku Usahatani } & n (orang) & \% \\
\hline Merawat pohon mangga agar produktvitasnya tinggi & 10 & 7,69 \\
\hline Selalu & 44 & 33,85 \\
Sering & 62 & 47,69 \\
Kadang-kadang & 14 & 10,77 \\
Jarang & 0 & 0,00 \\
Tidak pernah & & \\
\hline Menerapkan sistem pemupukan yang benar (dalam hal jenis, dosis & & \\
atau waktu pemupukan) & 6 & 4,62 \\
\hline Selalu & 85 & 65,38 \\
Sering & 30 & 23,08 \\
Kadang-kadang & 7 & 5,38 \\
Jarang & 2 & 1,54 \\
Tidak pernah & & \\
\hline Menggunakan teknologi hormon ZPT (zat perangsang tumbuh) & & \\
sesuai aturan pakai & 1 & 0,77 \\
\hline Selalu & 49 & 37,69 \\
Sering & 61 & 46,92 \\
Kadang-kadang & 19 & 14,62 \\
Jarang & 0 & 0,00 \\
Tidak pernah & \multicolumn{2}{c}{} \\
\hline Mengendalikan OPT dengan benar (misalnya penanganan hama & 3 & 2,31 \\
lalat buah dan hama lainnya) & 41 & 31,54 \\
\hline Selalu & 82 & 63,08 \\
Sering & 4 & 3,08 \\
Kadang-kadang & 0 & 0,00 \\
\hline Jarang & &
\end{tabular}

Menurut sebagian besar petani, jenis hama yang sering menyerang tanaman tanaman mangga milik petani adalah lalat buah, dan seringkali serangan lalat buah menimbulkan kerugian bagi petani. Lalat buah biasanya menyerang satu bulan sebelum waktu panen mangga. Sebagian besar petani membasmi lalat 
buah menggunakan bahan kimia. Kebanyakan petani melakukan penyemprotan insektisida tanpa memperhatikan populasi lalat buah yang menyerang tanaman. Petani rutin menyemprot tanamannya mulai dari tanaman mulai berbunga sampai menjelang waktu panen dengan frekuensi dua sampai tiga kali per minggu. Menurut petani cara tersebut dilakukan sebagai langkah pencegahan serangan lalat buah. Hal ini bertentangan dengan anjuran dari pemerintah. SOP budidaya mangga di Kabupaten Cirebon menganjurkan agar petani melakukan pengendalian hama secara biologis, mekanik dan kultur teknis, namun petani kebanyakan menggunakan insektisida kimia karena dirasa lebih cepat dan efektif dalam mengendalikan hama. Supriatna dan Sudana (2008) menjelaskan penggunaan pestisida untuk mengatasi serangan lalat buah denga prinsip preventif dan terjadwal justru tidak efisien secara ekonomi dan tidak dapat dipertanggungjawabkan secara ekologis.

\section{Faktor-faktor yang Berhubungan dengan Perilaku Petani dalam Usahatani Mangga}

Hasil analisis korelasi rank Spearman pada Tabel 5 menunjukkan jumlah pohon yang dimiliki petani berkorelasi positif dengan perawatan pohon mangga $(r s=0,242)$. Semakin banyak pohon mangga yang diusahakan oleh petani, semakin intensif petani merawat pohon mangganya. Jumlah pohon dapat menggambarkan skala ekonomi petani. Penelitian Khanna (2001) serta Daberkow dan McBride (2003) menunjukkan bahwa skala usaha petani berpengaruh terhadap keputusan untuk mengadopsi inovasi dan menerapkan teknologi dalam usahatani yang dijalankan. BPS mengkategorikan petani yang memiliki jumlah pohon di atas 11 pohon termasuk petani kebun, dimana petani lebih berorientasi bisnis. Petani menyadari bahwa perawatan tanaman akan berdampak pada kualitas dan kuantitas mangga yang dihasilkan, yang akhirnya berpengaruh terhadap pendapatan yang mereka terima.

Pengalaman usahatani mangga berkorelasi negatif dengan perilaku petani dalam penerapan pupuk yang benar sesuai dengan anjuran pemerintah ( $\mathrm{rs}=-0,351)$. Artinya petani dengan pengalaman usahatani lebih lama cenderung mengabaikan anjuran cara dan dosis pemupukan sesuai dengan SOP. Petani melakukan pemupukan berdasarkan pengalamannya selama menjalankan usahatani mangga. Adanya 
kegiatan penyuluhan dan pertemuan dalam kelompok tani turut berperan dalam keputusan yang diambil petani terkait usahatani yang mereka jalankan.

Sejalan dengan hasil di atas, frekuensi petani dalam mengikuti kegiatan penyuluhan berkorelasi positif dengan perilaku petani dalam penerapan pupuk yang sesuai anjuran ( $\mathrm{rs}=0,178)$. Petani yang lebih sering mengikuti kegiatan penyuluhan, cenderung untuk menerapkan cara dan dosis pemupukan sesuai anjuran pemerintah. Singh et al
(2015) menyatakan bahwa kegiatan penyuluhan membantu petani untuk memperoleh informasi terbaru terkait aktivitas usahatani dan mendorong petani untuk menerapkan sebuah inovasi. Sayangnya, sebagian besar petani di Kabupaten Cirebon jarang mengikuti kegiatan penyuluhan. Kurangnya tenaga penyuluh dan keterbatasan anggaran penyuluhan berdampak pada kegiatan penyuluhan yang diberikan kepada petani (Antholt, 1994).

Tabel 5. Hasil Analisis Korelasi Faktor-faktor yang Berhubungan dengan Perilaku Petani dalam Usahatani Mangga di Kabupaten Cirebon

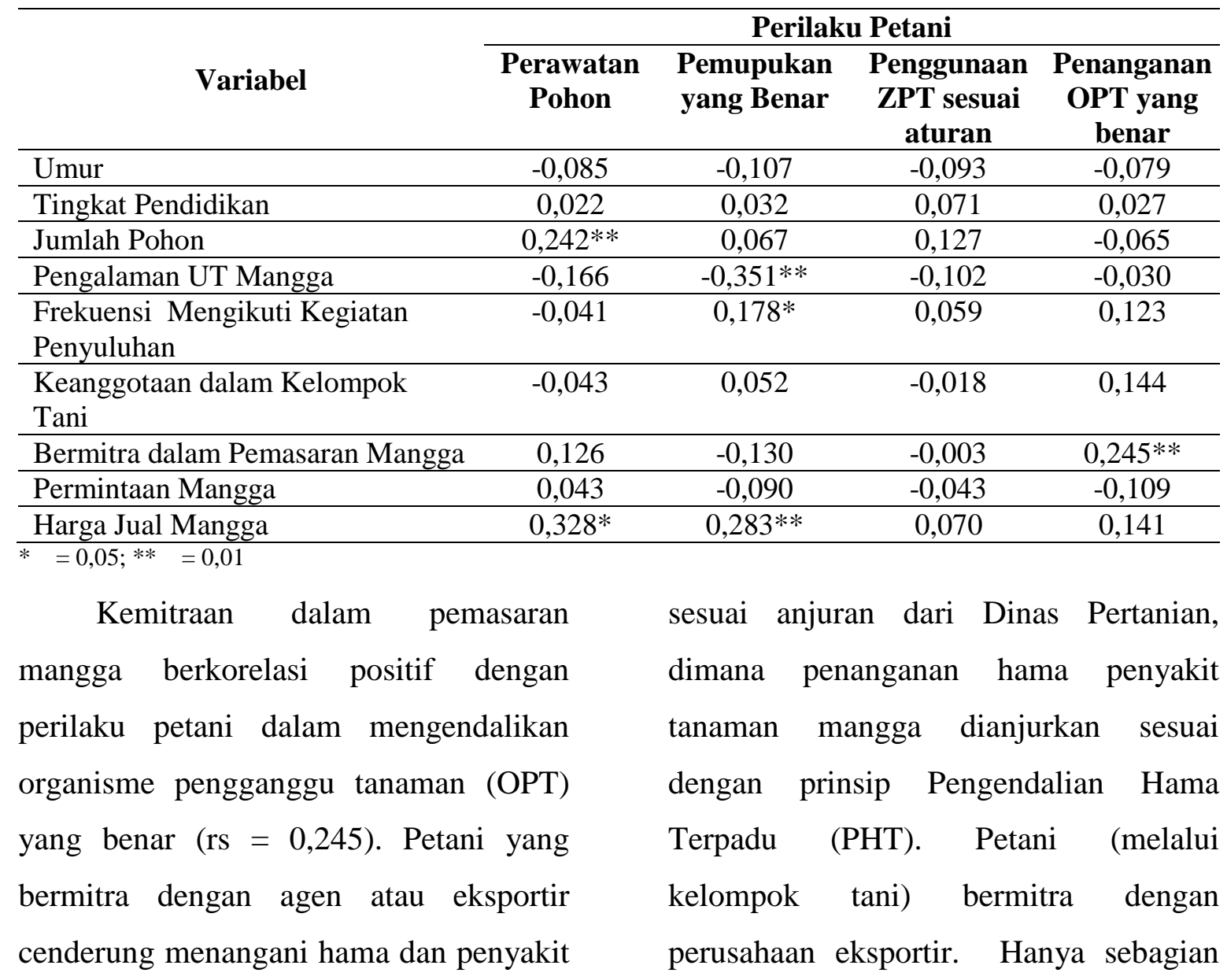


kecil petani yang bermitra dalam pemasaran mangga (Tabel 2), hal ini dikarenakan belum semua petani mampu memenuhi standar kualitas yang ditetapkan untuk pasar ekspor. Residu pestisida merupakan salah satu syarat yang diminta oleh beberapa pasar ekspor. Petani yang memasarkan mangganya untuk tujuan pasar ekspor berusaha untuk memenuhi persyaratan tersebut dengan mengurangi penggunaan bahan kimia dalam mengendalikan OPT, dan mengikuti cara penanganan OPT sesuai dengan prinsip PHT.

Harga jual mangga berkorelasi positif dengan perilaku petani dalam merawat tanaman $(\mathrm{rs}=0,238)$ dan penerapan pemupukan yang benar $(\mathrm{rs}=$ 0,283). Petani yang merasa harga jual yang mereka terima sudah baik, lebih bersemangat dalam menjalankan usahanya. Mosher (1997) mengemukakan bahwa harga merupakan salah satu faktor yang dapat memotivasi petani untuk meningkatkan produksinya. Petani bersedia untuk melalukan perawatan tanaman secara intensif, termasuk dalam hal dosis pemupukan apabila petani mendapatkan kepastian akan harga jual yang menguntungkan.

\section{PENUTUP}

Sebagian besar petani merasa permintaan mangga cukup tinggi dan harga jual mangga cukup menguntungkan, namun adanya fluktuasi harga jual menyebabkan petani kurang intensif dalam merawat tanaman mangga. Sebagian besar petani belum menerapkan teknis pemupukan, penggunaan zat pengatur tumbuh dan penanganan hama penyakit sesuai anjuran. Jumlah pohon yang dimiliki petani dan harga jual mangga berkorelasi dengan perilaku petani dalam merawat tanaman mangga. Sedangkan harga jual mangga dan lamanya pengalaman berusahatani berkorelasi dengan perilaku petani dalam pemupukan. Perilaku petani dalam penanganan organisme pengganggu tanaman berkorelasi dengan kemitraan yang terjalin dalam hal pemasaran mangga. Untuk memotivasi petani dalam merawat tanaman mangga secara intensif dan sesuai anjuran pemerintah, perlu dilakukan upaya untuk menjamin harga yang diterima oleh petani. Stabilitas harga dapat merangsang petani untuk meningkatkan produksi dan kualitas hasil mangga.

\section{DAFTAR PUSTAKA}

Ameriana, M. 2008. Perilaku Petani Sayuran dalam Menggunakan 
Pestisida Kimia. Jurnal Hortikultura, 18(1): 95-106.

Amin, M. 2014. Efektivitas dan Perilaku Petani dalam Memanfaatkan Teknologi Informasi Berbasis Cyber Extension. Jurnal Informatika Pertanian, 23(2): 211219.

Antholt, C.H. 1994. Getting Ready for The Twenty-first Century: Technical Change and Institutional Modernization in Agriculture. World Bank Technical Paper No.217. Washington D.C: World Bank.

Burton, Rob J.F. 2014. The Infulence of Farmer Demographic Characteristics on Environmental Behaviour: a Review. Journal of Environmental Management, 135(2014): 19-26.

Daberkow, S.G., McBride, W.D. 2003. Farm and Operator Characteristics Affecting the Awarness and Adoption of Precision Agriculture Technologies in the US. Precision Agriculture, 4(2): 163-177.

Deliana, Y. 2012. Do Producer and Consumer Care about Certification Label on Organic Vegetable. Proceeding Regional Symposium on Marketing and Finance of The Organic Supply Chain- SEOUL 2012, FAO- APRACA-AFMAIFOAM, 23-26 September .

Deliana,Y. 2013. Implikasi Label Asal Daerah (Origin Labelling) untuk Pemasaran Mangga Gedong Gincu. Laporan Akhir. PUPT. Bandung: Universitas Padjadjaran.

Dinas Pertanian Kabupaten Cirebon. 2004. Laporan Tahunan Dinas Pertanian Kabupaten Cirebon.
Direktorat Jenderal Bina Produksi Hortikultura. 2004. Buku Tahunan Hortikultura, Seri Tanaman Buah. Jakarta: Direktorat Jenderal Bina Produksi Hortikultura.

Direktorat Jenderal Hortikutura. 2006. Vademekum Mangga. Jakarta: Direktorat Jenderal Hortikutura Kementerian Pertanian.

Khanna, M. 2001. Sequentia Adoption of Site-Specific Technologies and its Implication for Nitrogen Productivity: a Double Selective Model. American Journal of Agriculture Economics, 83(1): 3551.

Mosher, A.T. 1997. Menggerakan dan Membangun Pertanian. Jakarta: CV Yasaguna.

Rakhmat, J. 2004. Psikologi Komunikasi. Bandung: PT Rosdakarya

Setiana. L. 2005. Teknik Penyuluhan dan Pemberdayaan Masyarakat. Bogor: Ghalia Indonesia.

Singh, M., Maharjan, K.L., Maskey, B. 2015. Factors Impacting Adoption of Organic Farming in Chitwan District of Nepal. Asian Economic and Social Society, 5(1): 1-12.

Supriatna, A., dan Sudana, W. 2008. Analisis Usahatani Mangga Gedong (Mangifera Indica spp) di Kabupaten Cirebon, Jawa Barat. Jurnal Pengkajian dan Pengembangan Teknologi Pertanian, 11(3): 218-229.

Yuniastuti, S., Handoko, Korlina, E., Purbiati, T., Yuwoko dan Bonimin. 2012. Kajian Formulasi Bahan Perangsang Pembungaan dan Pembuahan dalam Manajemen Pengaturan Pembuahan Mangga di Luar Musim. Laporan Hasil Kajian BPTP Jawa Timur. 